\title{
Growth, Phenology and Yield of Fenugreek (Trigonella foenum-graecum L.) as Influenced by Date of Sowing
}

\author{
Karma Chewang Bhutia ${ }^{1 *}$, Sonam Ongmu Bhutia ${ }^{2}$, Ranabir Chatterjee ${ }^{1}$ and \\ N. Chattopadhyay ${ }^{1}$ \\ ${ }^{1}$ Department of Spices and Plantation Crops, ${ }^{2}$ Department of Fruits and Orchard Management, \\ Faculty of Horticulture, Bidhan Chandra Krishi Viswavidyalaya, \\ Mohanpur, Nadia, West Bengal- 741252, India \\ *Corresponding author
}

\begin{tabular}{|c|c|}
\hline \multicolumn{2}{|r|}{ A B S T R A C T } \\
\hline & \multirow{6}{*}{$\begin{array}{l}\text { An experiment was carried out at Horticultural Research Station, Mondouri, BCKV, West } \\
\text { Bengal, India during } 2013-14 \text { and } 2014-15 \text { with an objective of evaluating the effects of } \\
\text { different sowing dates on growth, phenology and yield of fenugreek cultivar AFg-3 under } \\
\text { new alluvial plains of West Bengal. Six sowing dates viz. } 15 \text { days interval starting from } \\
15^{\text {th }} \text { October to } 30^{\text {th }} \text { December were considered. The experiment was laid out in RBD with } \\
\text { four replications. Significant difference on growth, phenology and yield of fenugreek was } \\
\text { observed for different sowing dates. Sowing date of } 30^{\text {th }} \text { October recorded maximum plant } \\
\text { height }(61.96 \mathrm{~cm}) \text {, number of branches }(7.50) \text {, pods per plant }(39.21) \text {, seed weight per pod } \\
(0.417 \mathrm{~g}) \text {, test weight }(12.38 \mathrm{~g}) \text {, seed yield per plot }(552.58 \mathrm{~g}) \text {, seed yield per hectare }(1.45 \\
\text { tonnes), shelling percentage }(68.16 \%) \text { and harvest index }(31.14 \%) \text {. Maximum pod length } \\
(12.41 \mathrm{~cm}) \text { and seeds per pod }(16.38) \text { was associated with } 15^{\text {th }} \text { November. Minimum days } \\
\text { taken for } 50 \% \text { flowering }(49.25 \text { days }) \text { and maturity }(111.00 \text { days }) \text { was observed in } 30^{\text {th }} \\
\text { November sowing, while } 50 \% \text { seed germination }(9.38 \text { days }) \text { was recorded with } 30^{\text {th }} \\
\text { October sowing. Therefore, planting fenugreek on } 30^{\text {th }} \text { October was recommended for } \\
\text { getting good net return due to better growth and yield. }\end{array}$} \\
\hline Keywords & \\
\hline & \\
\hline Article Info & \\
\hline $\begin{array}{l}\text { Accepted: } \\
\text { 17 September } 2017 \\
\text { Available Online: } \\
10 \text { October } 2017\end{array}$ & \\
\hline & \\
\hline
\end{tabular}

\section{Introduction}

Fenugreek (Trigonella foenum-graecum L., family -Leguminoceae) an annual herb is well known as flavour, curry powder and spice (Betty, 2008). It is originated in South Eastern Europe and West Asia. Today it is widely cultivated in India, Egypt, Argentina, China and America. Both seeds and green leaves are used as vegetables, food additives and fodder in South and Central Asian countries (Petropoulos, 2002). Fenugreek is grown for the purpose of green manuring in America.
Fenugreek seeds are frequently used in human medicine to manage hypercholesterolemia, cancer and diabetes mellitus as they possess hypoglycemic, antilipidemic, anticarcinogenic and cholagogic properties (Meghwal and Goswami, 2012). Fenugreek is a short duration crop and is suitable for various cropping system. Soon after harvesting of main kharif crops like chillies, cotton and paddy, fenugreek is grown as rabi crop. Among all the factors planting date has found to have direct influence on growth and yield 
attributing factors of fenugreek. However, variation in the monsoon has delayed the sowing time which hampers the growth, yield as well as quality of the crop (Seghat and Ahmadi, 2010; Abou Shleel, 2014). This paper focuses on the influence of different sowing dates on the growth and development of fenugreek under new alluvial plains of West Bengal.

\section{Materials and Methods}

Research was carried out at Horticultural Research Station, Mondouri, BCKV, West Bengal, India during 2013-14 and 2014-15 in the month of October to April for each year. The research location site is $23.5^{\circ}$ North latitude and $80^{\circ} \mathrm{E}$ longitude and at an altitude of $9.75 \mathrm{~m}$ above mean sea level. The research location experience a sub-tropical sub-humid type of climate and soil is Gangetic alluvial (entisol) with sandy clay loam texture having $\mathrm{pH}$ 6.9, good water holding capacity and medium fertility status. Fenugreek variety AFg-3 collected from NRCSS, Ajmer, India was used for this research.

The experiment was laid out in Randomized Block Design with four replications. The size of the main plot was made $3.24 \mathrm{~m}^{2}(1.8 \times 1.8$ $\mathrm{m})$. Sowing of the seeds were carried out in six different dates viz., $\mathrm{D}_{1}$ (15 ${ }^{\text {th }}$ October), $\mathrm{D}_{2}$ ( $30^{\text {th }}$ October $), D_{3}\left(15^{\text {th }}\right.$ November $), D_{4}\left(30^{\text {th }}\right.$ November $), D_{5}\left(15^{\text {th }}\right.$ December $)$ and $D_{6}\left(30^{\text {th }}\right.$ December). Farm yard manure @ 20 t/ha and NPK @ 30:40:30 kg/ha were applied during land preparation. Sowing rate was $25 \mathrm{~kg} / \mathrm{ha}$ and sowing depth was $2-3 \mathrm{~cm}$. The seeds were sown in continuous rows with a distance of 30 $\mathrm{cm}$ between rows. Irrigation immediately after planting was done in order to facilitate seed germination.

After 21 days of seeds germination, thinning of the plants was carried out to keep the distance between plants at $20 \mathrm{~cm}$ and to retain one plant per hill, maintaining 54 plants per plot. Immediately after thinning, first weeding and hoeing were carried out to control the weed growth. Subsequent weeding was carried out as per requirement. Irrigation was given by flooding at an interval of 15-20 days depending upon the moisture requirement of the soil and weather conditions.

\section{Collection of data}

Growth, phenological, yield and yield attributing parameters were studied during the experimental course. Growth parameters such as plant height, number of branches per plant were recorded during the end of vegetative phase. The seeds were harvested during the full maturation stage and thereafter yield and yield attributing parameters such as pods per plant, pod length, seeds per pod, seed weight per pod, test weight, seed yield per plot, seed yield per hectare, shelling percentage and harvest index were recorded. Three phenological parameters viz., days to $50 \%$ germination, days to $50 \%$ flowering and maturity duration was also recorded for each plot. Data were collected from the inner rows of each plot to avoid the border effect. In each unit plot, 10 plants were selected randomly for recording data on different morphological and yield contributing characters for seed. Shelling percentage and harvest index for individual plots was calculated using the given formula mentioned as follows:

Shelling $\%=\frac{\text { Weight } \text { of seeds }}{\text { Weight of pods }}$

Harvest Index $(\%)=\frac{\text { Economic yield }}{\text { Biological Yield }}$

\section{Statistical analysis}

The data collected were subjected to analysis of variance (ANOVA) by using the MSTATC statistical package (MSTAT-C, Version 1.41, 
Crop and Sciences Department, Michigan

State University, USA). The mean comparison was done following the Duncan's Multiple Range Test (DMRT).

\section{Results and Discussion}

The pooled analysis (Tables 1 and 2) of the two years data indicated that the sowing dates under evaluation varied significantly in all the characters under study. The results pertaining to different parameters are mentioned below.

\section{Days to 50\% germination}

Different sowing dates differed significantly for days to $50 \%$ germination (Table 1), which ranged from 9.38 to 14.13 days. The sowing date of $30^{\text {th }}$ December recorded maximum number of days (14.13 days) to reach 50\% germination. The second maximum days required for $50 \%$ germination was obtained from $15^{\text {th }}$ December sowing date (12.63 days) which was having no significant difference with $30^{\text {th }}$ November sowing date (12.25 days).

The minimum days required for $50 \%$ germination was achieved by fenugreek plants sown during $30^{\text {th }}$ October (9.38 days) which was at par with $15^{\text {th }}$ October sowing date (9.63 days). Late sowing exposed plants to low temperature at the time of emergence, which caused slow germination of the seeds. This result is in close conformity to that of Sultana et al., (2016) who observed that the days taken for germination of fenugreek seed was least on $2^{\text {nd }}$ November.

\section{Days to 50\% flowering}

The days required for 50\% flowering (from the date of sowing) in different sowing dates differed significantly, which ranged from 49.25 to 61.50 days (Table 1). The sowing date of $30^{\text {th }}$ November took minimum number of days (49.25 days) to reach $50 \%$ flowering stage followed by $30^{\text {th }}$ December (52.00 days) and $15^{\text {th }}$ December $(54.63$ days $)$. The maximum days taken to reach the 50\% flowering stage was observed with $15^{\text {th }}$ October sowing (61.50 days). The results regarding days to $50 \%$ flowering are more or less in consonance with the results of Sultana et al., (2016) who stated that the minimum number of days required for $50 \%$ flowering was observed with $28^{\text {th }}$ November sowing date.

\section{Maturity duration}

The sowing dates varied significantly in this trait (Table 1). Different planting dates took 111.00 to 133.00 days for maturity. The sowing date of $30^{\text {th }}$ November (111.00 days) took minimum number of days to reach maturity stage followed by $30^{\text {th }}$ December (115.75 days) and $15^{\text {th }}$ December (124.50 days). Maximum time taken for reaching maturity duration was observed with fenugreek plants sown during $15^{\text {th }}$ October (133.00 days). Under late sowing, prevalence of low temperature at early stage and high temperature at terminal phase of the crop might have caused forced maturity. Sultana $e t$ al., (2016) reported that fenugreek plants sown during $28^{\text {th }}$ November took least time for attaining crop maturity. Therefore the present findings support the result of Sultana et al., (2016).

\section{Plant height}

The plant height for different treatments differed significantly and ranged from 32.96 to $61.96 \mathrm{~cm}$ (Table 1). Fenugreek plants sown during $30^{\text {th }}$ October recorded maximum plant height $(61.96 \mathrm{~cm})$ followed by $15^{\text {th }}$ November $(55.13 \mathrm{~cm})$ and $15^{\text {th }}$ October planting $(51.33$ $\mathrm{cm})$. The lowest plant height was observed with the plants sown during $30^{\text {th }}$ December $(32.96 \mathrm{~cm})$. The increase in plant height of the crop seems to be on account of exposure of plants to many favourable climatic conditions. A decreasing trend on plant height was 
observed from $30^{\text {th }}$ October onwards. Nandre et al., (2011) obtained highest fenugreek plant height on $1^{\text {st }}$ November sowing date. They also observed decrease in plant height with an increment in sowing date at 15 days interval starting from $1^{\text {st }}$ November to $1^{\text {st }}$ December. The report of Nandre et al., (2011) is line with the present findings. The results are also in conformity with Sultana et al., (2016), as they obtained maximum plant height on $2^{\text {nd }}$ November sowing date.

\section{Number of branches}

Significant variation was observed among different sowing dates with respect to number of branches per plant ranging from 4.95 to 7.50 (Table 1). Sowing date of $30^{\text {th }}$ October produced the maximum number of branches (7.50) followed by $15^{\text {th }}$ November (6.53) and least was noticed with $30^{\text {th }}$ December sowing (4.95). Number of branches recorded for plants sown during $15^{\text {th }}$ October (6.28) was comparable with $30^{\text {th }}$ November (6.18) sowing date. This might be due to availability of favourable climatic conditions during early sowing that produced better vegetative growth. Similar results were observed by Korla and Saini (2003), Nandre et al., (2011) and Sultana et al., (2016).

\section{Pods per plant}

Marked variation was observed among the sowing dates in respect to number of pods per plant ranging from 23.83 to 39.21 (Table 2). The highest number of pods per plant was observed with $30^{\text {th }}$ October sowing date, which was followed by $15^{\text {th }}$ November (35.42) and $15^{\text {th }}$ October (32.92). The lowest number of pods per plant was observed with $30^{\text {th }}$ December sowing date.

This might be owing to favourable environmental conditions available to the crop during its initial growth and flowering stages. The present findings are in close agreement with the findings of Yadav et al., (2000), Gill et al., (2001), Korla and Saini (2003) and Bhutia and Sharangi (2016) in fenugreek.

\section{Pod length}

The pod length of different sowing dates differed significantly and ranged from 8.03 to $12.41 \mathrm{~cm}$ (Table 2). The sowing date of $15^{\text {th }}$ November $(12.41 \mathrm{~cm})$ gave the maximum pod length followed by $30^{\text {th }}$ October $(11.36 \mathrm{~cm})$ and $15^{\text {th }}$ October $(10.35 \mathrm{~cm})$. While, significantly minimum $(8.03 \mathrm{~cm})$ pod length were produced under the treatment $30^{\text {th }}$ December sowing date.

Table.1 Growth and phenological characters as influenced by different sowing dates (Pooled data of 2 years)

\begin{tabular}{lccccc}
\hline Sowing date & $\begin{array}{c}\text { Days to 50\% } \\
\text { germination }\end{array}$ & $\begin{array}{c}\text { Days to 50\% } \\
\text { flowering }\end{array}$ & $\begin{array}{c}\text { Maturity } \\
\text { duration }(\text { days })\end{array}$ & $\begin{array}{c}\text { Plant height } \\
(\mathbf{c m})\end{array}$ & $\begin{array}{c}\text { Number of } \\
\text { branches per plant }\end{array}$ \\
\hline $\mathrm{D}_{1}$ & $9.63 \mathrm{~d}$ & $61.50 \mathrm{a}$ & $133.00 \mathrm{a}$ & $51.33 \mathrm{c}$ & $6.28 \mathrm{c}$ \\
$\mathrm{D}_{2}$ & $9.38 \mathrm{~d}$ & $59.25 \mathrm{~b}$ & $129.75 \mathrm{~b}$ & $61.96 \mathrm{a}$ & $7.50 \mathrm{a}$ \\
$\mathrm{D}_{3}$ & $10.50 \mathrm{c}$ & $57.00 \mathrm{c}$ & $126.88 \mathrm{c}$ & $55.13 \mathrm{~b}$ & $6.53 \mathrm{~b}$ \\
$\mathrm{D}_{4}$ & $12.25 \mathrm{~b}$ & $49.25 \mathrm{f}$ & $111.00 \mathrm{f}$ & $46.13 \mathrm{~d}$ & $6.18 \mathrm{c}$ \\
$\mathrm{D}_{5}$ & $12.63 \mathrm{~b}$ & $54.63 \mathrm{~d}$ & $124.50 \mathrm{~d}$ & $38.83 \mathrm{e}$ & $5.65 \mathrm{~d}$ \\
$\mathrm{D}_{6}$ & $14.13 \mathrm{a}$ & $52.00 \mathrm{e}$ & $115.75 \mathrm{e}$ & $32.96 \mathrm{f}$ & $4.95 \mathrm{e}$ \\
$\mathrm{SEm}( \pm)$ & 0.266 & 0.288 & 0.281 & 0.534 & 0.078 \\
$\mathrm{CD}(\mathrm{P}=0.05)$ & 0.802 & 0.877 & 0.855 & 1.623 & 0.238 \\
\hline \multicolumn{5}{c}{$\left(\mathrm{D}_{1}-15^{\text {th }}\right.$ October, $\mathrm{D}_{2}-30^{\text {th }}$ October, $\mathrm{D}_{3}-15^{\text {th }}$ November, $\mathrm{D}_{4}-30^{\text {th }}$ November, $\mathrm{D}_{5}-15^{\text {th }}$ December, $\mathrm{D}_{6}-30^{\text {th }}$} \\
December $)$
\end{tabular}


Table.2 Yield and its component as influenced by different sowing dates (Pooled data of 2 years)

\begin{tabular}{|c|c|c|c|c|c|c|c|c|c|}
\hline Sowing date & $\begin{array}{l}\text { Pods } \\
\text { per } \\
\text { plant }\end{array}$ & $\begin{array}{l}\text { Pod length } \\
\quad(\mathrm{cm})\end{array}$ & $\begin{array}{c}\text { Seeds } \\
\text { per pod }\end{array}$ & $\begin{array}{c}\text { Seed } \\
\text { weight per } \\
\text { pod }(\mathrm{g})\end{array}$ & $\begin{array}{c}\text { Test } \\
\text { weight } \\
\text { (g) }\end{array}$ & $\begin{array}{c}\text { Seed yield } \\
\text { per plot } \\
\text { (g) }\end{array}$ & $\begin{array}{c}\text { Seed yield } \\
\text { per } \\
\text { hectare } \\
\text { (tonnes) }\end{array}$ & $\begin{array}{c}\text { Shelling } \\
\text { percentage }\end{array}$ & $\begin{array}{c}\text { Harvest } \\
\text { Index } \\
(\%)\end{array}$ \\
\hline $\mathrm{D}_{1}$ & $32.92 \mathrm{c}$ & $10.35 \mathrm{c}$ & $15.79 b$ & $0.366 \mathrm{c}$ & $11.29 \mathrm{c}$ & $474.79 c$ & $1.25 \mathrm{c}$ & $65.71 \mathrm{~b}$ & $28.86 b$ \\
\hline $\mathrm{D}_{2}$ & $39.21 \mathrm{a}$ & $11.36 \mathrm{~b}$ & $16.12 \mathrm{a}$ & $0.417 \mathrm{a}$ & $12.38 \mathrm{a}$ & $552.58 \mathrm{a}$ & $1.45 \mathrm{a}$ & $68.16 \mathrm{a}$ & $31.14 \mathrm{a}$ \\
\hline $\mathrm{D}_{3}$ & $35.42 b$ & $12.41 \mathrm{a}$ & $16.38 \mathrm{a}$ & $0.386 b$ & $11.71 \mathrm{~b}$ & $505.07 \mathrm{~b}$ & $1.33 b$ & $63.55 \mathrm{c}$ & $26.36 \mathrm{c}$ \\
\hline $\mathrm{D}_{4}$ & $29.17 d$ & $9.41 \mathrm{~d}$ & $15.46 \mathrm{c}$ & $0.318 \mathrm{~d}$ & $10.64 d$ & $456.57 \mathrm{~d}$ & $1.20 \mathrm{~d}$ & $62.22 \mathrm{~d}$ & $24.76 \mathrm{~d}$ \\
\hline $\mathrm{D}_{5}$ & $26.12 \mathrm{e}$ & $8.55 \mathrm{e}$ & $15.29 \mathrm{c}$ & $0.287 \mathrm{e}$ & $10.33 \mathrm{e}$ & $422.64 \mathrm{e}$ & $1.11 \mathrm{e}$ & $60.44 \mathrm{e}$ & $22.02 \mathrm{e}$ \\
\hline $\mathrm{D}_{6}$ & $23.83 \mathrm{f}$ & $8.03 \mathrm{f}$ & $14.67 d$ & $0.219 \mathrm{f}$ & $9.87 \mathrm{f}$ & $355.83 \mathrm{f}$ & $0.93 f$ & $59.68 \mathrm{e}$ & $21.15 \mathrm{e}$ \\
\hline $\operatorname{SEm}( \pm)$ & 0.387 & 0.090 & 0.108 & 0.001 & 0.041 & 0.643 & 0.002 & 0.433 & 0.410 \\
\hline $\mathrm{CD}(\mathrm{P}=0.05)$ & 1.177 & 0.275 & 0.329 & 0.003 & 0.124 & 1.879 & 0.007 & 1.307 & 1.235 \\
\hline
\end{tabular}




\section{Seeds per pod}

The seeds per pod for different sowing dates differed significantly and ranged from 14.67 to 16.38 (Table 2). The sowing date of $15^{\text {th }}$ November (16.38) produced highest number of seeds per pod which was at par with $30^{\text {th }}$ October (16.12). The lowest seed per pod was found in plants sown during $30^{\text {th }}$ December (14.67). Nandre et al., (2011) found that fenugreek plants sown during $1^{\text {st }}$ November produced significantly the maximum seeds per pod. Bhutia and Sharangi (2016) obtained highest seeds per pod with $23^{\text {rd }}$ November sowing. Sultana et al., (2016) also observed that highest seeds per pod were produced when fenugreek seeds were sown in $23^{\text {rd }}$ November. The findings of the present investigation are close to Nandre et al., (2011).

\section{Seed weight per pod}

The sowing dates varied significantly in this trait ranging from 0.219 to $0.417 \mathrm{~g}$ (Table 2). The maximum seed weight per pod was obtained from $30^{\text {th }}$ October $(0.417 \mathrm{~g})$, followed by $15^{\text {th }}$ November $(0.386 \mathrm{~g})$ and $15^{\text {th }}$ October $(0.366 \mathrm{~g})$. While, the sowing date of $30^{\text {th }} \quad$ December produced significantly minimum $(0.219 \mathrm{~g})$ weight of seeds per pod. The present findings are similar with the results recorded by the earlier workers like Lal et al., (2003), Nandre et al., (2011) and Sultana et al., (2016) in fenugreek.

\section{Test weight}

Test weight for different sowing dates was significantly found to be different. The test weight ranged from 9.87 to $12.38 \mathrm{~g}$ (Table 2). The highest test weight was recorded with $30^{\text {th }}$ October $(12.38 \mathrm{~g})$ sowing date followed by $15^{\text {th }}$ November $(11.71 \mathrm{~g})$ and $15^{\text {th }}$ October $(11.29 \mathrm{~g})$. Sowing of the fenugreek seeds on $30^{\text {th }}$ December $(9.87 \mathrm{~g})$ recorded the least test weight. Higher test weight in $30^{\text {th }}$ October sown plants is due to the fact that crop got sufficient time for its growth under favourable condition. This result is in close conformity to that of Bhutia and Sharangi (2016) and Sultana et al., (2016), who recorded the highest test weight with $2^{\text {nd }}$ November sowing date.

\section{Seed yield per plot}

Different date of sowing exhibited a significant variation in respect of seed yield per plot (Table 2). The plot yield ranged from 355.83 to $552.58 \mathrm{~g}$. The sowing date of $30^{\text {th }}$ October gave maximum seed yield per plot $(552.58 \mathrm{~g})$. The second maximum seed yield per plot was obtained from $15^{\text {th }}$ November $(505.07 \mathrm{~g})$ followed by $15^{\text {th }}$ October (474.79 g). The lowest seed yield per plot was recorded in $30^{\text {th }}$ December sowing date $(355.83 \mathrm{~g})$. The cumulative effect of higher values of yield attributes during $30^{\text {th }}$ October sowing date led to production of higher yield. It is an established fact that sinks capacity largely governs crop productivity (Evans, 1975).

\section{Seed yield per hectare}

Different sowing dates under investigation showed a wide range of variability on seed yield per hectare (Table 2). It ranged from 0.93 to 1.45 tonnes. The maximum seed yield was obtained from $30^{\text {th }}$ October sowing (1.45 $\mathrm{t} / \mathrm{ha})$ followed by $15^{\text {th }}$ November (1.33 t/ha) and $15^{\text {th }}$ October (1.25 t/ha). The lowest seed yield was found with $30^{\text {th }}$ December planting $(0.93 \mathrm{t} / \mathrm{ha})$. The possible reason for low yield in delayed sowing might be due to insufficient time for vegetative growth as the plant entered the reproductive phase at a faster rate. According to Nandre et al., (2011), the highest seed yield of fenugreek per hectare was obtained during $1^{\text {st }}$ November sowing. Lal et al., (2003) also found the similar results 
in fenugreek. Bhutia and Sharangi (2016) and Sultana et al., (2016) obtained highest seed yield with the $2^{\text {nd }}$ November sown crops. Thus the results of the present study are in accordance with all the records of earlier work done by Lal et al., (2003), Nandre et al., (2011), Bhutia and Sharangi (2016) and Sultana et al., (2016).

\section{Shelling percentage}

The maximum shelling percentage was obtained from $30^{\text {th }}$ October $(68.16$ per cent) followed by $15^{\text {th }}$ October (65.71 per cent) and $15^{\text {th }}$ November (63.55 per cent). The lowest shelling percentage was recorded with $30^{\text {th }}$ December (59.68 per cent), which was at par with $15^{\text {th }}$ December (60.44 per cent). According to Anitha et al., (2016), the highest shelling percentage was recorded on $15^{\text {th }}$ October sowing date, which was at par with the $1^{\text {st }}$ November sown plants.

\section{Harvest index}

Different sowing dates showed significant variation in respect of harvest index (Table 2). The harvest index ranged from 21.15 to 31.14 per cent. Sowing date of $30^{\text {th }}$ October gave maximum harvest index (31.14 per cent) followed by $15^{\text {th }}$ October (28.86 per cent) and $15^{\text {th }}$ November (26.36 per cent). Fenugreek plants sown during $30^{\text {th }}$ December gave minimum harvest index (21.15 per cent) which was at par with plants sown during $15^{\text {th }}$ December (22.02 per cent).

This might be due to better vegetative growth in terms of more number of branches per plant and more number of pods per plant due to better photosynthetic efficiency and translocation of photosynthates from source to sink. Moghaddam et al., (2014) reported that sowing of cumin on $5^{\text {th }}$ November resulted in maximum harvest index than that sown on $5^{\text {th }}$ December and $5^{\text {th }}$ March.
The study indicated that the sowing dates had significant influence on the growth, phenology and yield of fenugreek. It was evident from the results obtained that sowing of fenugreek early at $30^{\text {th }}$ October is recommended for getting good growth and higher yield. Reduction in yield has also been observed with the delay in sowing date in respect to different parameters. However, the experiment should be carried out for another 2 to 3 years to confirm the results under the new alluvial zones of West Bengal.

\section{References}

Abou Shleel, S. M., 2014. Effect of air temperature on growth, yield and active ingredients of fenugreek (Trigonella foenum-graecum). Nature and Science, 12(9): 50-54.

Anitha, B., Lakshmi Narayana Reddy, M., Dorajee Rao, A. V. D., Kiran Patro, T. S. K. K. and Salomi Suneetha, D. R. 2016. Effect of Sowing Date on Yield and Quality of Fenugreek. Plant Archives, 16(1): 479-484.

Betty, R., 2008. The Many Healing Virtues of Fenugreek. Spice India. Pp. 17-19.

Bhutia, P. H., and Sharangi, A. B. 2016. Effect of Dates of Sowing and Soil Moisture Level in Different Growth Stages and Yield Dynamics of Fenugreek (Trigonella foenum-graecum L.). Natl. Acad. Sci. Lett., 39(2): 77-80.

Evans, L. T., 1975. Crop Physiology. Cambridge University Press, London. Pp 375.

Gill, B. S., Randhawa, G. S. and Saini, S. S. 2001. Effect of sowing dates and herb cutting management on growth and yield of fenugreek (Trigonella foenumgraecum L.). Indian J. of Agron, 46(2): 364-367.

Korla, B. N., and Saini, A. 2003. Effect of dates of sowing and cutting on seed yield of fenugreek. Haryana J. Hort. 
Sci., 32: 120-122.

Lal, S., Rana, M. K. and Pratap, P. S. 2003. Effect of date of sowing and green cuttings on quality of different fenugreek genotypes. Haryana J. Hort. Sci., 32(3/4): 262-265.

Meghwal, M., and Goswami, T. K. 2012. A review on the functional properties, nutritional content, medicinal utilization and potential application of fenugreek. J. Food Process Technol., 3(9): 181.

Moghaddam, P. R., Moradi, R. and Mansoori, H. 2014. Influence of planting date, intercropping and plant growth promoting rhizobacteria on cumin (Cuminum cyminum L.) with particular respect to disease infestation in Iran. $J$. Appl. Res. Med. Aromat. Plants, 1: 134143.

Nandre, D. R., Ghadge, R. G. and Rajput, B. S. 2011. Effect of sowing dates and nutrient management on growth and seed yield fenugreek. Adv. Res. J. Crop
Improv, 2(2): 215-220.

Petropoulos, G. A., 2002. Fenugreek- The genus Trigonella, Taylor \& Francis Inc Publishing House, London. Pp. 1-255.

Seghat, A. M. J., and Ahmadi, B. K. H. 2010. The effect of sowing date and plant density on yield and yield components of fenugreek (Trigonella foenumgraecum L.). Iran J. Med. Aromat. Plants, 2(2): 265-267.

Sultana, S., Das, G., Das, B. and Sarkar, S. 2016. Influence of dates of sowing on growth and yield dynamics of fenugreek (Trigonella foenum-graecum L.). International J. of Green Pharm., 10(4): 233-236.

Yadav, J. S., Jagdev, S., Virendra, K. and Yadav, B. D. 2000. Effect of sowing time, spacing and seed rate on seed yield of fenugreek (Trigonella foenumgraecum L.) on light textured soil. Haryana Agri. Univ. J. Res., 30(3-4): 107-111.

\section{How to cite this article:}

Karma Chewang Bhutia, Sonam Ongmu Bhutia, Ranabir Chatterjee and Chattopadhyay, N. 2017. Growth, Phenology and Yield of Fenugreek (Trigonella foenum-graecum L.) as Influenced by Date of Sowing. Int.J.Curr.Microbiol.App.Sci. 6(10): 1810-1817. doi: https://doi.org/10.20546/ijcmas.2017.610.218 